\title{
Effectiveness of Problem Based Learning (PBL) Towards Learning Outcomes Through Critical Thinking Skills
}

\author{
Buyung Adi Dharma ${ }^{1}$, Nikmatul Tasrikah ${ }^{2}$, Madziatul Churiyah $^{3}$ \\ 1,2,3 Universitas Negeri Malang \\ Email: buyung.adi.fe@um.ac.id
}

(Received: August 2020; revised: November 2020; published: November 2020)

\begin{abstract}
The learning model is one of the important roles that has components and it is important to note that a learning model can be performed properly. The purpose of this study is to determie the effect of Problem Based Learning (PBL) on learning outcomes through critical thinking. This research is quasi experimental with posttest only control group design. Analysis of data using Two Way Anova. The result of this research shows that (1) There is a difference between students who are taught by using teaching model PBL and students who are not taught by using teaching model PBL. (2) There is a difference in learning outcomes between high critical thinking skills with low critical thinking skills. (3) There is an effect between Problem Based Learning model with the ability to think critically in learning outcomes.
\end{abstract}

Keywords: Learning model, problem based learning (PBL), learning outcomes, critical thinking

\section{INTRODUCTION}

Over the past few years, education has undergone changes in terms of learning process and curriculum renewal (Arhas, 2018),(McCann et al., 2020), (Bravo \& Alves, 2019), (Machali, 2014). Learning in the 21 st century demands a new generation of students and workers who think critically and creatively, as well as character (Susilawati et al., 2015), develop knowledge and skills (Buabeng-Andoh, 2012). This has an impact on the learning process to be diverse and interesting, the learning environment becomes better with cooperation between individuals, even technology and techniques in teaching are needed (Lou et al., 2011). One of the teaching techniques so that the learning process can be better through the use of learning models.

The learning model is one of the important roles that has components and it is important to note that a learning model can be performed properly. components include design and implementation (Hanum, 2013). One of the design of learning models that can make the learning process better is to use the Problem Based Learning (PBL) learning model (Liu et al., 2019), (Park \& Choi, 2015), (Kek \& Huijser, 2011). The Problem Based Learning (PBL) learning model is an active learning model that can support creativity in developing knowledge, improving self-teaching skills, teamwork, problem solving skills and critical thinking skills (Hsu et al., 2016), (Lin et al., 2010).

Several studies have developed the Problem Based Learning (PBL) model, in which it was developed in IPA learning materials (Cahyaningsih \& Ghufron, 2016), geography learning (Maulidiyahwarti \& Amirudin, 2016), even in nursing (Park \& Choi, 2015), ((Vittrup \& Davey, 2010), (Lin et al., 2010). Based on some research it can be concluded that the use of Problem Based Learning (PBL) model can be used as a reference for teachers in conducting good teaching activities. the use of such models can also improve critical thinking skills and learning

Copyright (C) 2020 Universitas Negeri Makassar. This is an open access article under the CC BY license (http://creativecommons.org/licenses/by/4.0/) 


\author{
236 Jurnal Administrare: Jurnal Pemikiran Ilmiah dan Pendidikan Administrasi Perkantoran \\ Volume 7 Number 2 July- December 2020. Pages 235-244
}

outcomes of students (Khatiban \& Sangestani, 2014).

Based on the results of interviews with teachers at SMK Terpadu Al-Ishlahiyah Singosari it is known that critical thinking skills and student learning outcomes in general administration subjects are still not optimal. The learning process still uses the method of lectures, causing students to be less enthusiastic about learning. Some of the students who responded to what had been conveyed by the teacher at the time were given a understanding in asking or expressing their opinions. Learning media facilities are also less optimal, given the limited number of projector LCD. Therefore, this research aims to determine the effect of the Problem Based Learning (PBL) model on learning outcomes through students' critical thinking skills in general administration subjects for Students of Grade X Office Governance Automation at AlIshlahiyah Singosari Integrated Vocational School.

The use of problem based learning (PBL) models is sought to address problems related to learning outcomes and critical thinking skills of students. Some research by (Park \& Choi, 2015), (Martyn et al., 2014), (Wulandari \& Surjono, 2013), (Kek \& Huijser, 2011) states that there has been a significant improvement in learning attitudes, decision making, problem solving skills, critical thinking, and motivation. However, in previous research there is still nothing to prove that the Problem Based Learning (PBL) model can improve learning outcomes through critical ness. It can only prove to increase one of the variables between learning outcome variables and critical thinking variables. Based on this, researchers conducted research using the Problem Based Learning (PBL) model on learning results through critical thinking skills.

\title{
METHOD
}

This research is a type of quasi experiment with the design of research using Posttest Onlt Control Group Design. This study aims to find out the differences in the learning outcomes of students who use models with those who do not use the model, to know the difference in learning outcomes between high critical thinking ability and low thinking ability, and to know how models influence learning outcomes through critical thinking abilities.

The subjects of this study were all students of class X OTKP at SMK Terpadu AlIshlahiyah Singosari. There are two classes used and taken by looking at abilities that are almost identical to midterm test scores (UTS). The determination of the expansive class and control class is determined using purposive sampling or intentional retrieval. Classes with high average grades are defined as control classes and given treatment using conventional models (variation lectures), while classes with low average grades are assigned as experiment classes and given treatment using the Problem Based Learning (PBL) model.

Research instruments used include critical thinking skills instruments and cognitive learning instruments in the form of essays. Critical thinking instruments refer to critical thinking indicators, including formulating problems, giving arguments, concluding, evaluating, and providing solutions (Sumarmo et al., 2012), (Mulnix, 2012). The study instrument refers to the cognitive realm of $\mathrm{C} 2-\mathrm{C} 6$ according to bloom taxonomy. Instrument development procedures are carried out through validity and reliability tests. Data analysis was conducted using the Anova Two Way Anova test with the help of the SPSS 24.0 for Windows program. 


\section{RESULT AND DISCUSSION}

Data on critical thinking skills and learner results are obtained from tests given to students after treatment. The data of the study results is obtained from posttest scores, while critical thinking ability data is obtained from test scores before posttest. Data descriptions of critical thinking abilities and learning outcomes can be found in Table 1 and Table 2.

Table 1 Critical Thinking Ability Data

\begin{tabular}{ccccccc}
\hline \multirow{2}{*}{$\begin{array}{c}\text { Class } \\
\text { Learners }\end{array}$} & $\begin{array}{c}\text { Experimental } \\
\text { Class }\end{array}$ & $\mathrm{f}$ & $\%$ & Control Class & $\mathrm{F}$ & $\%$ \\
\hline High & 82.5 & 16 & $57.2 \%$ & 76.81 & 11 & $39.3 \%$ \\
\hline Low & 63.1 & 12 & $42.8 \%$ & 60.73 & 17 & $60.7 \%$ \\
\hline Average & 74.2 & 28 & & 67.05 & 28 & \\
\hline
\end{tabular}

Source : Research processed data. 2020

Based on Table 1, it can be noted that the average value of critical thinking abilities of the two classes is different. The experiment class had an average score of 74.2 , the control class had an average score of 67.05 .

Table 2 Learning Results Data

\begin{tabular}{ccccccc}
\hline \multirow{2}{*}{$\begin{array}{c}\text { Class } \\
\text { Learners }\end{array}$} & $\begin{array}{c}\text { Experimental } \\
\text { Class }\end{array}$ & $\mathrm{f}$ & $\%$ & Control Class & $\mathrm{F}$ & $\%$ \\
\hline High & 82.44 & 18 & $64.3 \%$ & 79.43 & 14 & $50 \%$ \\
\hline Low & 68.40 & 10 & $35.7 \%$ & 59.71 & 14 & $50 \%$ \\
\hline Average & 77.43 & 28 & & 69.57 & 28 & \\
\hline
\end{tabular}

Source : Research processed data. 2020

Based on Table 2, it can be noted that the average score of the learning outcomes of both classes is different. The experiment class had an average score of 77.43 , the control class had an average score of 69.57. From Table 1 and Table 2 it can be concluded that the classes treated by the Problem Based Learning (PBL) model have an average value of critical thinking ability and higher learning outcomes than classes that get conventional learning treatment (variation lectures).

While the results of the two-track Anova test (Two Way Anova) on critical thinking ability data and the learning results of experiment class students and control classes can be seen in Table 3 . 
238 Jurnal Administrare: Jurnal Pemikiran Ilmiah dan Pendidikan Administrasi Perkantoran

Volume 7 Number 2 July- December 2020. Pages 235-244

Table 3 Two Way Anova Test Results

Tests of Between-Subjects Effects

\begin{tabular}{lrrrrr}
\hline Dependent Variable: & hasil belajar & & & & \\
\hline \multicolumn{1}{c}{ Source } & $\begin{array}{c}\text { Type III Sum } \\
\text { of Squares }\end{array}$ & \multicolumn{1}{c}{ Df } & Mean Square & \multicolumn{1}{c}{ F } & \multicolumn{1}{c}{ Sig. } \\
\hline Corrected Model & $4852.870^{\mathrm{a}}$ & 3 & 1617.623 & 59.864 & .000 \\
\hline Intercept & 281799.788 & 1 & 281799.788 & 10428.635 & .000 \\
\hline Class & 458.852 & 1 & 458.852 & 16.981 & .000 \\
\hline Think & 3819.046 & 1 & 3819.046 & 141.332 & .000 \\
\hline Class * Think & 107.727 & 1 & 107.727 & 3.987 & .051 \\
\hline Error & 1405.130 & 52 & 27.022 & & \\
\hline Total & 308784.000 & 56 & & & \\
\hline Corrected Total & 6258.000 & 55 & & & \\
\hline
\end{tabular}

a. $\mathrm{R}$ Squared $=.775$ (Adjusted $\mathrm{R}$ Squared $=.763$ )

Based on Table 3 it is known that the signification value of the study results test between classes using the Problem Based Learning (PBL) model and classes using conventional models (variation lectures) of $0.000<0.05$. So it can be concluded that there are differences in the learning outcomes of students using the Problem Based Learning (PBL) model with conventional models (variation lectures). The results of the experiment class study had a higher average score than the control class. This is because in the learning process of Problem Based Learning (PBL) there are stages of bloating group investigation that can strengthen each other's interaction and communication so that the skills in expressing themselves develop, the activeness and courage of the learners in expressing their opinions increases, the knowledge of the learners increases and better understands the material conveyed (Khatiban \& Sangestani, 2014). This makes the learning outcomes better, too. The results of the study showed the ability and quality of the students as a result of the learning process that he went through (Nurhasanah \& Sobandi, 2016).

\section{Discussion}

There is collaborative learning at the stage of developing and presenting work and in the stage of analyzing and evaluating problem solving that can assist students in listening to and respecting the opinions of others, so that in this case it can develop skills and build good communication (Hsu et al., 2016). The Problem Based Learning (PBL) learning process also emphasizes strengthening concepts in real situations, highlevel thinking skills, and problem-solving skills (Supiandi \& Julung, 2016), as well as developing various types of investigative activities and effective collaboration capabilities (Sasson et al., 2018). 
Problem Based Learning (PBL) also has advantages that can involve students in the process of learning according to real life, not only focusing on the problem-solving process in finding solutions but taking responsibility in developing other skills (Ali, 2019), no longer given learning materials in one direction as in the lecture model (Anggraini \& Mukhadis, 2013). In contrast to variety lecture learning, students gain knowledge from teachers to receive materials and not build their own knowledge (Qomariyah, 2016).

There is a difference in learning outcomes between high critical thinking ability and low critical thinking ability, seen in Table 3 that the signification value for thinking is $0.000<0.05$. This means that students who have high critical thinking skills can explicitly improve their learning outcomes (Kek \& Huijser, 2011) by students who have low critical thinking skills.

Improving critical thinking skills in improving learning outcomes depends not only on academic ability and knowledge, but on effective teaching knowledge and methods by being given a problem can challenge students to develop critical thinking (Espey, 2018). There are indicators of evaluating arguments on the given issue so as to guide development and make judgments in taking action (Geçit \& Akarsu, 2017). Indicators provide solutions also play a role in improving critical thinking skills and resulting in logical decisions towards solving a problem (Dwyer et al., 2014).

The importance of critical thinking is able to master new situations and problems so that students have the awareness to design, monitor, and assess what to learn (Ejin, 2017) receive unlimited information, face and solve complex problems, as well as technology and social changes that are changing faster (Vong \& Kaewurai, 2017), (Geçit \& Akarsu, 2017), (Ridho et al., 2019).

Critical thinking should also be trained on students because it is necessary to analyze their thoughts and make choices and draw precise conclusions (Nuryanti et al., 2018), so that in this case students are required to be active in learning to use problems related to real situations and encourage interaction between students to share different points of view (Oliveras et al., 2013). High academic ability in material mastery will affect his learning outcomes and have a higher speed of thinking anyway (Dehghani et al., 2011).

There is an influence between problem based learning (PBL) learning models and critical thinking skills on learning outcomes. Based on Table 3 it appears that the test results obtained a signification value of 0.051 and Fhitung of 3,987 > Ftabel. This is because the Problem Based Learning (PBL) model uses the problem as a first step that can gather and integrate new knowledge and help students to find suitable solutions (Muhson, 2009), (Weiss, 2017). Group learning can also affect critical thinking skills and student learning outcomes. Students collaborate with each other and discuss in determining the subject matter that has been given. The collaboration process here aims to help students in producing solutions (Kuvac \& Koc, 2018). In the Problem Based Learning (PBL) learning model, group learning can apply what has been learned by 


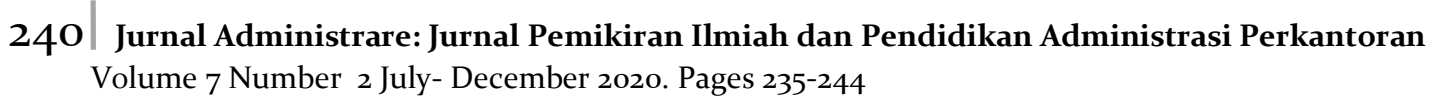

discussion in the classroom and outside the classroom, which can stimulate the development of their abilities (Luo, 2019). This results in students being able to develop critical thinking skills and find solutions to solve the problem.

The Problem Based Learning (PBL) model also has a phase of providing solutions and drawing conclusions that can encourage the critical thinking skills of students because it is also included in critical thinking ability indicators (Setyowati \& Subali, 2011). The evaluation process can also affect critical thinking skills and learning outcomes in using the Problem Based Learning (PBL) model used for reflection activities (Supiandi \& Julung, 2016). Reflection activities can also help improve the quality of learning, critical and collaborative skills among students (Yew \& Goh, 2016). Sehinga in this case positively impacts the memory of students on the materials taught and can affect learning outcomes. The Problem Based Learning (PBL) model in influencing the development of critical thinking skills and improving learning outcomes can also be based on the purpose of the model itself whereby not only learning to acquire knowledge, but allowing students to acquire skills to determine the course of their own learning process (Luo, 2019).

\section{CONCLUSION}

Based on the results of data analysis and discussion, it was concluded that (1) There were differences in student learning outcomes between classes using the Problem Based Learning (PBL) learning model and conventional models (variation lectures). (2) There is a difference in learning outcomes between high critical thinking ability and low critical thinking ability. (3) Problem Based Learning (PBL) learning models with critical thinking skills affect learning.

\section{REFERENCES}

Ali, S. (2019). Problem Based Learning: A Student-Centered Approach. English Language Teaching, 12(5), P73. Https://Doi.Org/10.5539/Elt.V12n5p73

Anggraini, V. D., \& Mukhadis, A. (2013). Motivasi Belajar, Kemampuan Awal, Dan Hasil Belajar Siswa Smk. 19(2), 187-195. Https://Doi.Org/10.17977/Jip.V19i2.42111

Arhas, S. H. (2018). Metode Pembelajaran Black Knight. Apa? Mengapa? dan Bagaimana? Jurnal Ad'ministrare, 5(2), 165-172.

Bravo, I., \& Alves, M. P. (2019). The Curriculum Development Process: An Overview Of The Educational System In Ecuador. Euro-JCS, 5(1), ArticleHttp://Pages.Ie.Uminho.Pt/Ejcs/Index.Php/Ejcs/Article/View/192

Buabeng-Andoh, C. (2012). Factors Influencing Teachers' Adoption And Integration Of Information And Communication Technology Into Teaching: A Review Of The Literature. 8(1), 136-155. 
Cahyaningsih, U., \& Ghufron, A. (2016). Pengaruh Penggunaan Model Problem-Based Learning Terhadap Karakter Kreatif Dan Berpikir Kritis Dalam Pembelajaran Matematika. Jurnal Pendidikan Karakter, 1. Https://Doi.Org/10.21831/Jpk.V0i1.10736

Dehghani, M., Sani, H. J., Pakmehr, H., \& Malekzadeh, A. (2011). Relationship Between Students' Critical Thinking And Self-Efficacy Beliefs In Ferdowsi University Of Mashhad, Iran. Procedia - Social And Behavioral Sciences, 15, 2952-2955. Https://Doi.Org/10.1016/J.Sbspro.2011.04.221

Dwyer, C. P., Hogan, M. J., \& Stewart, I. (2014). An Integrated Critical Thinking Framework For The 21st Century. Thinking Skills And Creativity, 12, 43-52. Https://Doi.Org/10.1016/J.Tsc.2013.12.004

Ejin, S. (2017). Pengaruh Model Problem Based Learning (PBL Terhadap Pemahaman Konsep Dan Keterampilan Berpikir Kritis Siswa Kelas IV SDN Jambu Hilir Baluti 2 Pada Mata Pelajaran Ilmu Pengetahuan Alam. Jurnal Pendidikan (Teori Dan Praktik), 1(1), 66. Https://Doi.Org/10.26740/Jp.V1n1.P66-72

Espey, M. (2018). Enhancing Critical Thinking Using Team-Based Learning. Higher Education $\begin{array}{llll}\text { Research } \quad \text { Development, } & \text { 37(1), }\end{array}$ Https://Doi.Org/10.1080/07294360.2017.1344196

Geçit, Y., \& Akarsu, A. H. (2017). Critical Thinking Tendencies Of Geography Teacher Candidates In Turkey. Universal Journal Of Educational Research, 5(8), 1362-1371. Https://Doi.Org/10.13189/Ujer.2017.050809

Hanum, N. S. (2013). Keefektifan E-Learning Sebagai Media Pembelajaran (Studi Evaluasi Model Pembelajaran E-Learning Smk Telkom Sandhy Putra Purwokerto). Jurnal Pendidikan Vokasi, 3(1), 90-102. Https://Doi.Org/10.21831/Jpv.V3i1.1584

Hsu, C., Yen, S., \& Lai, W. (2016). The Effect Of Problem-Based Learning On Learning Outcomes Of Accounting Students. Asian Journal Of Finance \& Accounting, 8(2), 135. Https://Doi.Org/10.5296/Ajfa.V8i2.9917

Kek, M. Y. C. A., \& Huijser, H. (2011). The Power Of Problem-Based Learning In Developing Critical Thinking Skills: Preparing Students For Tomorrow's Digital Futures In Today's Classrooms. Higher Education Research \& Development, 30(3), 329-341. Https://Doi.Org/10.1080/07294360.2010.501074

Khatiban, M., \& Sangestani, G. (2014). The Effects Of Using Problem-Based Learning In The Clinical Nursing Education On The Students' Outcomes In Iran: A Quasi-Experimental Study. Nurse Education In Practice, 14(6), 698-703. Https://Doi.Org/10.1016/J.Nepr.2014.10.002

Kuvac, M., \& Koc, I. (2018). The Effect Of Problem-Based Learning On The Environmental Attitudes Of Preservice Science Teachers. Educational Studies, 1-23. Https://Doi.Org/10.1080/03055698.2018.1443795 

242 Jurnal Administrare: Jurnal Pemikiran Ilmiah dan Pendidikan Administrasi Perkantoran
Volume 7 Number 2 July- December 2020. Pages 235-244

Lin, C.-F., Lu, M.-S., Chung, C.-C., \& Yang, C.-M. (2010). A Comparison Of Problem-Based Learning And Conventional Teaching In Nursing Ethics Education. Nursing Ethics, 17(3), 373-382. Https://Doi.Org/10.1177/0969733009355380

Liu, L., Du, X., Zhang, Z., \& Zhou, J. (2019). Effect Of Problem-Based Learning In Pharmacology Education: A Meta-Analysis. Studies In Educational Evaluation, 60, 4358. Https://Doi.Org/10.1016/J.Stueduc.2018.11.004

Lou, S. J., Liu, Y. H., Shih, R. C., \& Tseng, K. H. (2011). The Senior High School Students' Learning Behavioral Model Of STEM In PBL. International Journal Of Technology And Design Education, 21(2), 161-183. Https://Doi.Org/10.1007/S10798-010-9112-X

Luo, Y.-J. (2019). The Influence Of Problem-Based Learning On Learning Effectiveness In Students' Of Varying Learning Abilities Within Physical Education. Innovations In Education And Teaching International, 56(1), 3-13. Https://Doi.Org/10.1080/14703297.2017.1389288

Machali, I. (2014). Kebijakan Perubahan Kurikulum 2013 Dalam Menyongsong Indonesia Emas Tahun 2045. Jurnal Pendidikan Islam, 3(1), 71-94. Https://Doi.Org/10.14421/Jpi.2014.31.71-94

Martyn, J., Terwijn, R., Kek, M. Y. C. A., \& Huijser, H. (2014). Exploring The Relationships Between Teaching, Approaches To Learning And Critical Thinking In A ProblemBased Learning Foundation Nursing Course. Nurse Education Today, 34(5), 829-835. Https://Doi.Org/10.1016/J.Nedt.2013.04.023

Maulidiyahwarti, G., \& Amirudin, A. (2016). Pengaruh Model Problem Based Learning Berbasis Outdoor Study Terhadap Hasil Belajar Siswa Kelas Xi Iis Sma. 1(2), 7. Https://Doi.Org/10.17977/Jp.Vi.6101

Mccann, E., Powell, S., Becher, E. H., \& Mcguire, J. K. (2020). Reinvisioning Coparent Curriculum: Meeting The Needs Of A Changing Population. Adult Learning, 1045159519892681. Https://Doi.Org/10.1177/1045159519892681

Muhson, A. (2009). Peningkatan Minat Belajar Dan Pemahaman Mahasiswa Melalui Penerapan Problem-Based Learning. 39(2), 12. Https://Doi.Org/10.21831jk.V39i2.212

Mulnix, J. W. (2012). Thinking Critically About Critical Thinking. Educational Philosophy And Theory, 44(5), 464-479. Https://Doi.Org/10.1111/J.1469-5812.2010.00673.X

Nurhasanah, S., \& Sobandi, A. (2016). MINAT BELAJAR SEBAGAI DETERMINAN HASIL BELAJAR SISWA. Jurnal Pendidikan Manajemen Perkantoran (Jpmanper), 1(1), 128-135. Https://Doi.Org/10.17509/Jpm.V1i1.3264

Nuryanti, L., Zubaidah, S., \& Diantoro, M. (2018). Analisis Kemampuan Berpikir Kritis Siswa SMP. 3(2), 4. Https://Doi.Org/10.17977/Jptpp.V3i2.10490 
Oliveras, B., Márquez, C., \& Sanmartí, N. (2013). The Use Of Newspaper Articles As A Tool To Develop Critical Thinking In Science Classes. International Journal Of Science Education, 35(6), 885-905. Https://Doi.Org/10.1080/09500693.2011.586736

Park, S., \& Choi, S. (2015). Effects Of Problem-Based Learning On The Learning Atti-Tudes, Critical Thinking Disposition And Problem-Solving Skills Of Nursing Students: Infant Care. 192-196. Https://Doi.Org/10.14257/Astl.2015.103.41

Qomariyah, E. N. (2016). Pengaruh Problem Based Learning Terhadap Kemampuan Berpikir Kritis IPS. 23(2), 10.

Ridho, S., Ruwiyatun, R., Subali, B., \& Marwoto, P. (2019). Analisis Kemampuan Berpikir Kritis Siswa Pokok Bahasan Klasifikasi Materi Dan Perubahannya. Jurnal Penelitian Pendidikan IPA, 6(1), 10. Https://Doi.Org/10.29303/Jppipa.V6i1.194

Sasson, I., Yehuda, I., \& Malkinson, N. (2018). Fostering The Skills Of Critical Thinking And Question-Posing In A Project-Based Learning Environment. Thinking Skills And Creativity, 29, 203-212. Https://Doi.Org/10.1016/J.Tsc.2018.08.001

Setyowati, A., \& Subali, B. (2011). Implementasi Pendekatan Konflik Kognitif Dalam Pembelajaran Fisika Untuk Menumbuhkan Kemampuan Berpikir Kritis Siswa Smp Kelas Viii. 7, 8. Https://Doi.Org/10.1529/Jpfi.V7i2.1078

Sumarmo, U., Hidayat, W., Zukarnaen, R., Hamidah, M., \& Sariningsih, R. (2012). Kemampuan Dan Disposisi Berpikir Logis, Kritis, Dan Kreatif Matematik (Eksperimen Terhadap Siswa SMA Menggunakan Pembelajaran Berbasis Masalah Dan Strategi Think-Talk-Write). Jurnal Pengajaran Matematika Dan Ilmu Pengetahuan Alam, 17(1), 17. Https://Doi.Org/10.18269/Jpmipa.V17i1.228

Supiandi, M. I., \& Julung, H. (2016). Pengaruh Model Problem Based Learning (PBL) Terhadap Kemampuan Memecahkan Masalah Dan Hasil Belajar Kognitif Siswa Biologi SMA. 4(2), 5. Https://Doi.Org/10.17977/Jps.V4i2.8183

Susilawati, S., Ristanto, S., \& Khoiri, N. (2015). Pembelajaran Real Laboratory Dan Tugas Mandiri Fisika Pada Siswa Smk Sesuai Dengan Keterampilan Abad 21. Jurnal Pendidikan Fisika Indonesia, 11(1), 73-83. Https://Doi.Org/10.15294/Jpfi.V11i1.4005

Vittrup, A.-C., \& Davey, A. (2010). Problem Based Learning - 'Bringing Everything Together' - A Strategy For Graduate Nurse Programs. Nurse Education In Practice, 10(2), 88-95. Https://Doi.Org/10.1016/J.Nepr.2009.03.019

Vong, S. A., \& Kaewurai, W. (2017). Instructional Model Development To Enhance Critical Thinking And Critical Thinking Teaching Ability Of Trainee Students At Regional Teaching Training Center In Takeo Province, Cambodia. Kasetsart Journal Of Social Sciences, 38(1), 88-95. Https://Doi.Org/10.1016/J.Kjss.2016.05.002

Weiss, G. (2017). Problem-Oriented Learning In Geography Education: Construction Of Motivating Problems. Journal Of Geography, 116(5),206-216. Https://Doi.Org/10.1080/00221341.2016.1272622 
$244 \mid$ Jurnal Administrare: Jurnal Pemikiran Ilmiah dan Pendidikan Administrasi Perkantoran Volume 7 Number 2 July- December 2020. Pages 235-244

Wulandari, B., \& Surjono, H. D. (2013). Pengaruh Problem-Based Learning Terhadap Hasil Belajar Ditinjau Dari Motivasi Belajar PLC Di SMK. Jurnal Pendidikan Vokasi, 3(2). Https://Doi.Org/10.21831/Jpv.V3i2.1600

Yew, E. H. J., \& Goh, K. (2016). Problem-Based Learning: An Overview Of Its Process And Impact On Learning. Health Professions Education, 2(2), 75-79. Https://Doi.Org/10.1016/J.Hpe.2016.01.004 